\title{
Recruitment patterns of decapod crustacean megalopae in a shallow inlet (SW Spain) related to life history strategies
}

\author{
J.I. González-Gordillo ${ }^{\mathrm{a}, *}$, A.M. Arias ${ }^{\mathrm{b}}$, A. Rodríguez ${ }^{\mathrm{b}}$, P. Drake \\ ${ }^{a}$ Departamento de Biología, Universidade de Aveiro, 3810-193 Aveiro, Portugal \\ ${ }^{\mathrm{b}}$ Instituto de Ciencias Marinas de Andalucía (CSIC), Apdo Oficial, 11510 Puerto Real, Cádiz, Spain
}

Received 18 May 2001; received in revised form 3 January 2002; accepted 13 March 2002

\begin{abstract}
Decapod crustacean megalopae were sampled weekly (spring/neap tides) during late-spring/summer of 1998 by using two planktonic nets located close to the surface and the bottom, at a fixed station in the mouth of the Río San Pedro inlet (SW Spain). Sampling was carried out during $25 \mathrm{~h}$ cycles to ascertain the flux of megalopae in relation to the main environmental (diel, tidal, tidal amplitude) cycles. The hypothesis that megalopae of some species may be using tidal-stream transport as a mechanism of reinvading the inlet was tested and the relationship between megalopal behaviour and life history strategy was analysed. In general, the flux of megalopae was higher during spring tides, but such differences were only statistically significant for Pisidia longicornis and Liocarcinus sp. 2 due to the considerable interdate variation. With the exception of Macropodia sp., megalopae were more abundant close to the bottom. The diel/tidal flux of most abundant species suggested two different patterns of behaviour: megalopae of Liocarcinus spp., Panopeus africanus, Uca tangeri and Brachynotus sexdentatus seemed to be re-invading the inlet (specially at nocturnal floods), while megalopae of Ilia nucleus, Nepinnotheres pinnotheres and Macropodia sp. may have been just looking for a suitable place for settlement. The first group corresponded to the species whose zoeal development occurs in open sea, and the second one to species that complete their life cycle within the studied system, suggesting a relationship between the duration of the larval phase and the life cycle strategy of the species.
\end{abstract}

(C) 2003 Elsevier Science B.V. All rights reserved.

Keywords: larvae; crustacean; decapoda; vertical migration; megalopal flux; tidal transport; Iberian Peninsula

\section{Introduction}

Two general life history strategies may be observed among decapod crustacean species inhabiting and spawning in estuarine habitats: retention of larvae within the estuarine system and export of early larval stages to coastal waters with the subsequent return of megalopae or juveniles to estuaries (Morgan, 1995). These general patterns are mainly influenced by the local tidal regime, which varies in relation to the geographical area, resulting in different time-patterns of larval hatching and recruitment in different areas (Pereira, Pereira, \& Queiroga, 2000). Although the larval transport of some estuarine invertebrates may be explained as the

\footnotetext{
* Corresponding author.

E-mail address: nacho.gonzalez@bio.ua.pt (J.I. González-Gordillo).
}

transport of passive particles, decapod larvae exhibit active behaviours that may facilitate their migration between estuarine and coastal waters (emigration), and vice versa (immigration) (Boehlert \& Mundy, 1988; Epifanio, 1988). For well-mixed systems, the selective tidal stream transport may represent a suitable mechanism for such larval migrations. Planktonic larvae, as decapod zoeae, may migrate vertically taking advantages of depth differences of the current speed. In particular, by moving up into the water column during ebb and descending near the bottom during flood, decapod zoeae are flushed out the estuarine habitats (Queiroga, Costlow, \& Moreira, 1997). Benthic stages, such as megalopae and juveniles of many species of decapod, may be buried in the bottom sediment or may be attached to benthic substrata and then migrate to the water when the current is flowing in the suitable direction. Flood-tide transport, moving down during 
ebb and ascending in the water column during flood, has been suggested for megalopae re-invading estuaries (Cronin, 1982; Olmi, 1994; Queiroga, 1998; Tankersley, McKelvey, \& Forward, 1995). In summary, for decapods which complete their life cycle within estuaries, larval retention in the estuary may be the primary mechanism of recruitment to estuarine adult population (Sandifer, 1975), whilst for species whose larvae are flushed into the open sea, immigration of megalopae or juveniles from coastal waters is the major mechanism by which the parental population is re-stocked (Dittel \& Epifanio, 1990; Epifanio, 1995; Johnson \& Perry, 1999; Little \& Epifanio, 1991; Queiroga, 1998; Tankersley et al., 1995; Wehrtmann \& Dittel, 1990).

The Río San Pedro is a shallow inlet located in the east shore of the Bay of Cádiz (SW Spain). It was originally a branch of the Guadalete River Estuary, but human activity and sedimentary processes have changed it into a marine tidal inlet with an insignificant inflow of fresh water. Most decapod species inhabiting the Bay of Cádiz and the studied inlet, mainly use them as an adult habitat and spawning ground, while larval development occurs in the open sea. Furthermore, not all decapod species that complete their life cycle within the Bay of Cádiz seem to do it in the Río San Pedro inlet (Drake, Arias, \& Rodríguez, 1998). Since vertical migration has not been observed for exported larvae, the tidal synchronization of female release has been suggested as the most probable mechanism of larval exportation (Drake et al., 1998; Rodríguez et al., 1997). According to the available information from other estuarine areas, immigration of megalopae and/or juveniles to the inlet is the most plausible mechanism for re-stocking parental populations of the studied system.

The ecological relevance of Bay of Cádiz as nursery area for the early stages of commercial fish and decapod species (Drake et al., 1998; Rodríguez, Drake, \& Arias, 1997) has given rise to a research programme started in 1995 aiming to determine as to which mechanisms regulate hatching and recruitment of decapod larval stages in this area. The present study examines the hypothesis of a selective tidal transport of megalopae as a mechanism for re-invasion of the Río San Pedro inlet by analysing the temporal and vertical variations in flux of megalopae in relation to diel, tidal and spring/neap tidal cycles at the mouth of the inlet. Moreover, the distribution pattern of megalopae is compared to the life history strategies of the different species.

\section{Materials and methods}

\subsection{Study site}

This study was carried out in Río San Pedro, a shallow inlet of the salt marsh area of the Bay of Cádiz
(Spain) $\left(36^{\circ} 23^{\prime}-37^{\prime} \mathrm{N}, 6^{\circ} 8^{\prime}-15^{\prime} \mathrm{W}\right)$ (Fig. 1). It is a sinuous $12-\mathrm{km}$ long inlet, characterized by semidiurnal mesotides (average tidal range $0.98-3.20 \mathrm{~m}$ ) and a soft muddy bed with a subtidal cover of the alga Caulerpa prolifera. The tidal current flows from the bay along the inlet where the freshwater inflow is not significant, except during heavy rains.

The sampling station was located close to the mouth of the inlet, where the channel width is $\simeq 100 \mathrm{~m}$ at low spring tide and $\simeq 300 \mathrm{~m}$ at high spring tide. The inlet cross-section showed a continuously submerged channel ( $4.7 \mathrm{~m}$ below chart datum) on the SW side and a wide tidal flat (partially exposed at low tides) on the NE side (Fig. 1).

To estimate water flowing through the inlet during a 25-h period, its cross-sectional area was calculated at $1-\mathrm{h}$ intervals. The relation between cross-sectional area $(S)$ and water height ( $h$, above hydrographic 0 ) was:

$S=\mathrm{e}^{(5.329+0.376 h)}(r=0.98 ; P<0.01)$,

where $S$ and $h$ were measured in square metres and metres, respectively.

\subsection{Sampling}

Samples were collected in late spring and summer of 1998 (from 17 June to 31 August) because this is the season when most decapod species reproduce in the area (Drake et al., 1998). To quantify the vertical distribution and flux of megalopae along the water column, planktonic samples were taken weekly (11 sampling sets), coinciding with each spring and neap tide, using two conical planktonic nets each measuring $40 \mathrm{~cm}$ (mouth diameter) with meshes of $500 \mu \mathrm{m}$. The nets were attached to an anchored boat and samples were passively collected against the water current. One net sampled $10-30 \mathrm{~cm}$ below the surface, while the other sampled the strata of $10-30 \mathrm{~cm}$ above the bottom. Between both nets, vertical distance varied according to tidal level.

Each sampling comprised a 25-h sampling study, in which 32 samples (16 at the surface +16 at the bottom), lasting $60 \mathrm{~min}$ each, were collected. The samples were taken in synchrony with tidal phases, during each flood and ebb tide. Nets were consecutively, deployed four times during each tidal situation, beginning $1 \mathrm{~h}$ after slack-before-flood (or slack-before-ebb). At each time, the water volume filtered varied from 45 to $528 \mathrm{~m}^{3}$ in spring tides and from 14 to $432 \mathrm{~m}^{3}$ in neap tides. Unidirectional flow meters, placed in the mouth of each net, provided information to calculate sampled water volumes and current speeds. Water temperature and salinity were measured at the beginning and at the end of each deployment at the net depths $(\simeq 30 \mathrm{~cm}$ from the surface and above the bottom, respectively). 


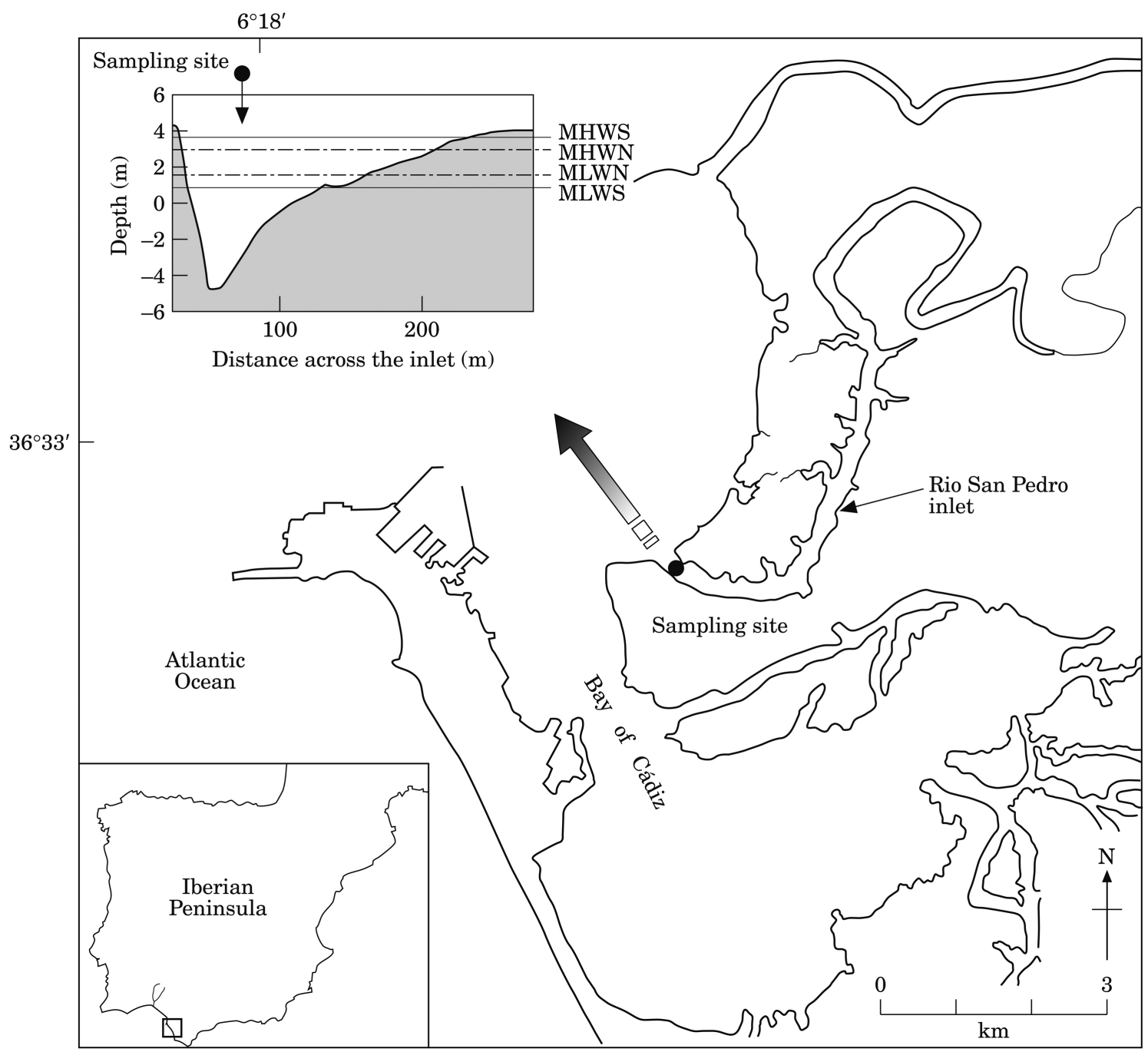

Fig. 1. Map of the studied area and cross-section of the Río San Pedro inlet at the zone where the sampling station was fixed. MHWS and MLWS, mean water levels at high and low tides, respectively, in spring tides; MHWN and MLWN, mean water levels at high and low tides, respectively, in neap tides.

Samples were fixed in 5\% buffered formalin immediately after collection. Megalopae were sorted in the laboratory and identified to species level, whenever possible, or to generic level when specific identification was not possible.

\subsection{Data analysis}

To test for differences in environmental conditions, water temperature, salinity and current speed, data were analysed by analysis of variance (ANOVA). When significant differences were detected, data were further analysed using a posteriori Student-Newman-Keuls test.

Density of decapod megalopae in a given sample was estimated as the number of individuals per $1 \mathrm{~m}^{3}$ of filtered water. Considering the different current speed and larval density at the surface and at the bottom of the water column, the flux (input at flood and output at ebb) of megalopae was estimated as the number of individuals passing every hour through a $1 \mathrm{~m}^{2}$ section. The megalopal flux of the most abundant species was statistically analysed by ANOVA.

For the nine most abundant species, the contribution of the factor spring/neap lunar phase to the variation observed in the mean flux of megalopae between sampling sets was ascertained using one-way ANOVA. Variables were log-transformed to reduce the nonnormality of the data and the heterogeneity of variances. Further statistical analyses were only performed for the five most abundant species ( $>100$ megalopae collected). For these species, because there was significant variation in total megalopal abundance between sampling sets, megalopal flux data were expressed at each diel/tidal/ depth situation as a percentage of the total number caught during each 25 -h series. The four samples taken at the same diel/tidal/depth situation were pooled to obtain a single estimate for each situation at each date. After this transformation, a four-way ANOVA was 
performed (for spring and neap tides separately) to test the effect of different factors (diel and tidal cycles, depth and date) on the flux of megalopae. For each four-way ANOVA, interactions of factors were estimated to the highest order allowed by data. Relative megalopal fluxes (\%) were arcsine $\sqrt{x}$-transformed prior to analysis. Factors detected to be significant by ANOVA were analysed using a posteriori Student-Newman-Keuls tests at the $5 \%$ significance level. When significant interactions were found, the comparisons of means for the main effects or lower order interactions of these factors were not considered. For each species, sampling sets with less than 10 megalopae were excluded from these statistical analyses.

In this study, sampling was designed to cover the complete tidal cycle. In addition, within each date, the four samples from each 'diel/tidal' situation were pooled before statistical analysis because they were not independent. Consequently, between spring and neap tides, and also from date to date, there were certain differences in light conditions, but a same diel/tidal condition has been considered. The nocturnal ebb included crepuscular (dawn) and early day samples during spring tides, but only authentic nocturnal samples during neap tides. Conversely, the nocturnal flood included crepuscular (dawn, except dusk on 17 August) and early day samples (late day on 17 August) during neap tides, but only authentic nocturnal samples during spring tides (Fig. 2).

\section{Results}

\subsection{Environmental conditions}

Water temperature ranged from 22.2 to $29.6^{\circ} \mathrm{C}$ over the 11 sampling sets, but varied $2.2^{\circ} \mathrm{C}$ within each sampling set, on average (Fig. 3). There were no significant differences $(P>0.05)$ in water temperature between the surface and the bottom. During each $25 \mathrm{~h}$ series, temperature was slightly lower during the night, especially during ebbs, although a diel/tidal difference was not significant $(P>0.05)$.

Salinity ranged between 36.5 and 43.5 over the 11 sampling sets, but varied 3.2 within each sampling set, on average (Fig. 3). The water column was well-mixed, and no significant differences $(P>0.05)$ were observed in salinity between the surface and the bottom. On the whole, salinity was lower $(P<0.01)$ during spring tides than during neap tides (mean salinity: 38.7 and 39.5 at spring and neap tides, respectively).

Current speed was significantly higher $(P<0.01)$ at spring tides (maximum value, $64.7 \mathrm{~m} \mathrm{~min}^{-1}$ ) than at neap tides (maximum value, $38.6 \mathrm{~m} \mathrm{~min}^{-1}$ ) (Fig. 3). Current speeds at the surface $\left(S_{\mathrm{s}}\right.$, at $\equiv 25 \mathrm{~cm}$ below surface) and at the bottom ( $S_{\mathrm{b}}$, at $\equiv 25 \mathrm{~cm}$ above the bottom) were correlated, but there were significant differences
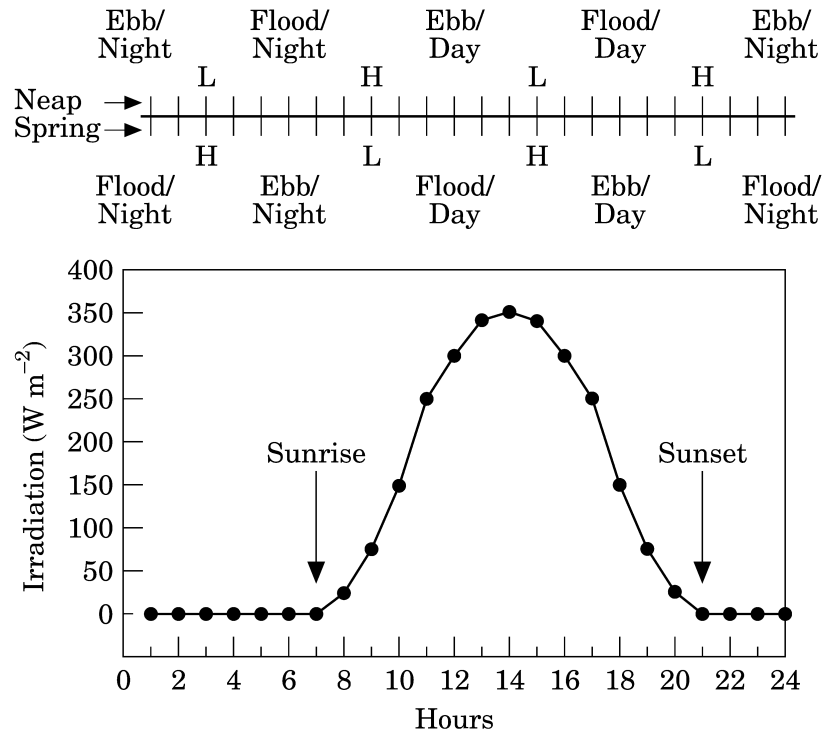

Fig. 2. Schematic diagram showing the diel/tidal situation during the period of study. The curve simulates the solar irradiation during $24 \mathrm{~h}$ (concretely for 1 July) and the superior bar indicates the tidal situation in neap (above the bar) and spring (below the bar) tides.

between them, greater during ebbs $\left(S_{\mathrm{b}}=0.77 S_{\mathrm{s}}\right.$; $r=0.75)$ than during floods $\left(S_{\mathrm{b}}=0.84 S_{\mathrm{s}} ; r=0.78\right)$. Depending on the tidal amplitude, the total volume of water flowing during $25 \mathrm{~h}$ ranged approximately from 4 to $9 \times 10^{6} \mathrm{~m}^{3}$ at neap tides and from 11 to $15 \times 10^{6} \mathrm{~m}^{3}$ at spring tides.

\subsection{Megalopal abundance}

A total of 11082 megalopae of decapod crustaceans, belonging to 20 different species, were collected over the 11 sampling sets. Only fluxes of the nine most abundant species (eight brachyuran and one anomuran species; $99.2 \%$ of the collected individuals) were analysed in this study (Table 1).

A mean megalopal flux of 3008 individuals $\mathrm{m}^{-2} \mathrm{~h}^{-1}$ was obtained over the 11 sampling sets, ranging between 161 and 1492 individuals $\mathrm{m}^{-2} \mathrm{~h}^{-1}$ on neap tides and from 20 to 19117 individuals $100 \mathrm{~m}^{-3}$ on spring tides (Table 1). Nevertheless, megalopal flux was only significantly higher $(P<0.05)$ on spring tides than neap tides for Pisidia longicornis and Liocarcinus sp.2 (Table 2).

\subsection{Diel, tidal and vertical flux patterns of megalopae}

In spring tides, the flux of megalopae was higher during nocturnal floods and close to the bottom (Fig. 4). Flux of Nepinnotheres pinnotheres megalopae was, however, higher at the nocturnal ebb on 17 June, and Macropodia sp. megalopae were more abundant at the surface in some sampling sets. However, megalopal flux patterns were more heterogeneous in neap tides. The flux of Panopeus africanus and Uca tangeri megalopae was also higher in 

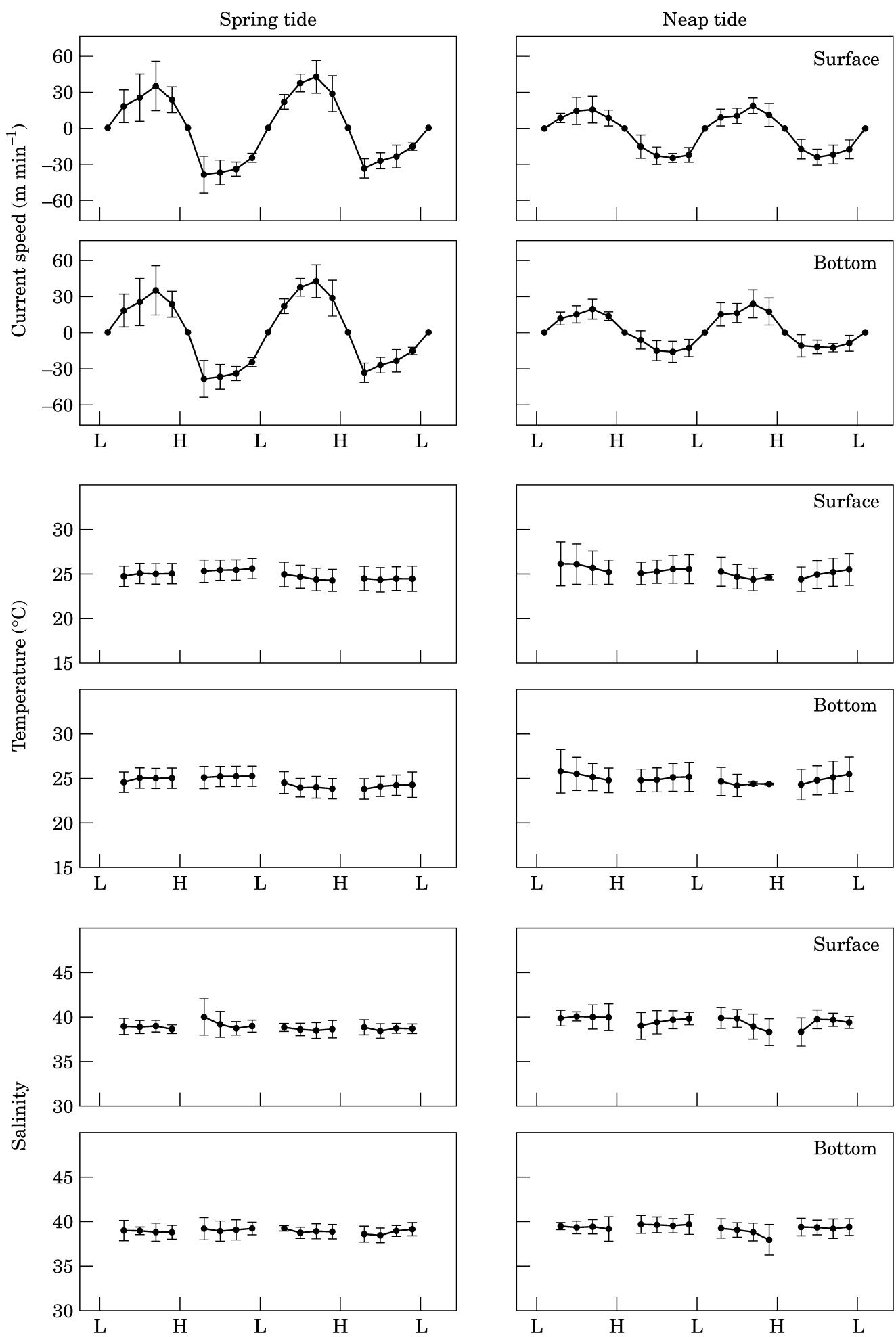

Fig. 3. Mean values and standard error of environmental conditions (current speed, water temperature and salinity) at the sampling site during all the $25 \mathrm{~h}$ sampling series in spring neap tides. $\mathrm{L}$ and $\mathrm{H}$, low and high tides, respectively.

nocturnal floods and close to the bottom, while for the two species of Liocarcinus, there was a maximal flux in both nocturnal and diurnal floods. A maximal flux of Pisidia longicornis and Brachynotus sexdentatus megalopae was recorded in the nocturnal flood or ebb depending on the sampling date, while Ilia nucleus, $N$. pinnotheres and Macropodia sp. megalopae did not show a clear diel/tidal/ depth pattern (Fig. 5).

The significance of such differences in flux pattern was only tested for the five most abundant species. 


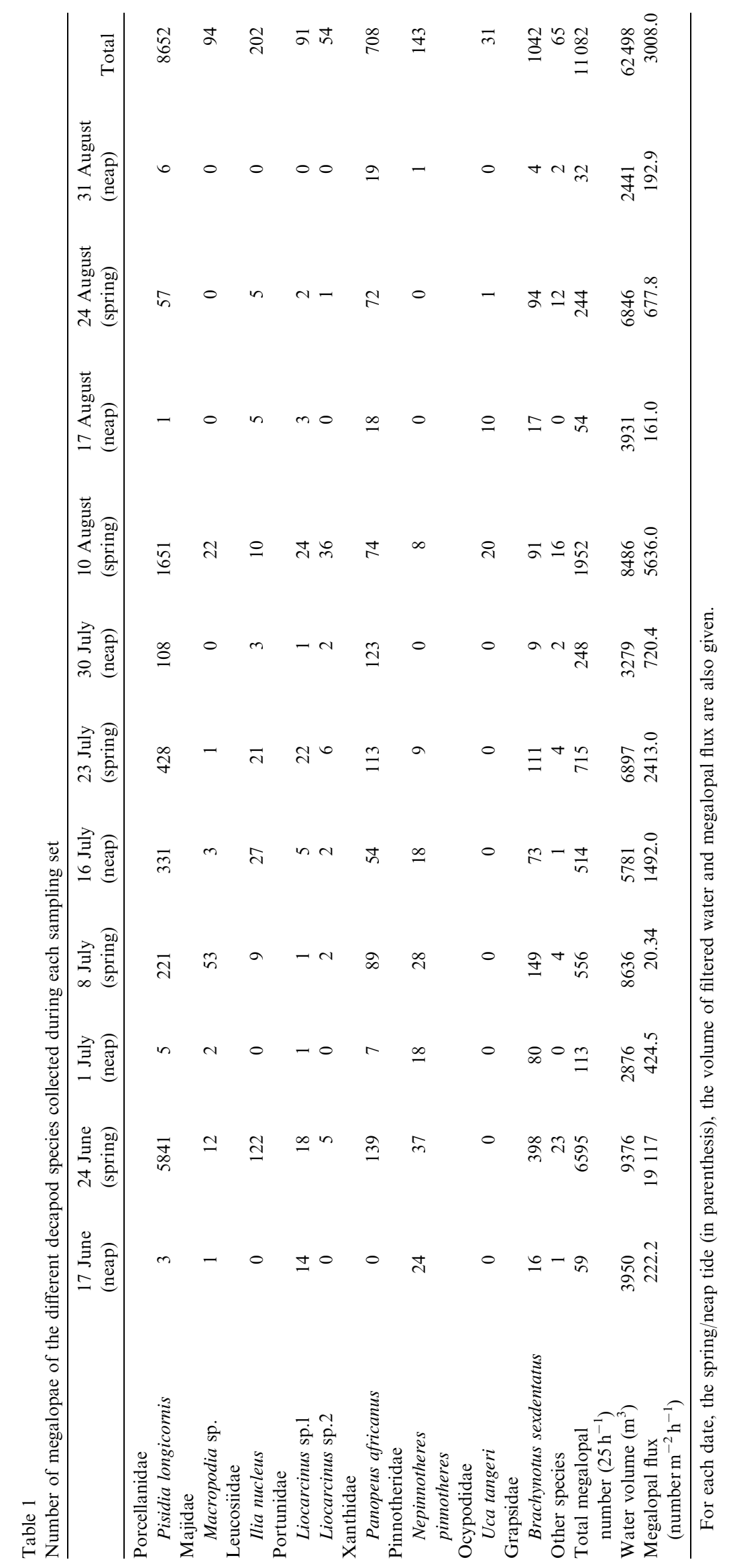


Table 2

Results of one-way ANOVAs of the effect of tidal amplitude (Sp and $\mathrm{Np}$, spring and neap tides, respectively) on the flux of decapod megalopae

\begin{tabular}{lllll}
\hline & & & & $\begin{array}{l}\text { Student- } \\
\text { Newman- }\end{array}$ \\
& Source of & & Mean & Keuls \\
Species & variation & df & square & $\left({ }^{*} P<0.05\right)$ \\
\hline Pisidia longicornis & Tidal amplitude & 1 & 40.37 & $\mathrm{Sp}>\mathrm{Np}{ }^{*}$ \\
& Residuals & 9 & 4.12 & \\
Ilia nucleus & Tidal amplitude & 1 & 243.99 & $\mathrm{Sp}=\mathrm{Np}$ \\
& Residuals & 9 & 48.81 & \\
Liocarcinus $\mathrm{sp} .1$ & Tidal amplitude & 1 & 33.01 & $\mathrm{Sp}=\mathrm{Np}$ \\
Liocarcinus $\mathrm{sp} .2$ & Residuals & 9 & 25.67 & \\
& Tidal amplitude & 1 & 350.30 & $\mathrm{Sp}>\mathrm{Np}$ \\
Panopeus africanus & Residuals & 9 & 36.73 & \\
& Tidal amplitude & 1 & 46.78 & $\mathrm{Sp}=\mathrm{Np}$ \\
Nepinnotheres & Residuals & 9 & 32.08 & \\
pinnotheres & Tidal amplitude & 1 & 20.61 & $\mathrm{Sp}=\mathrm{Np}$ \\
Uca tangeri & Residuals & 9 & 73.16 & $\mathrm{Sp}=\mathrm{Np}$ \\
& Tidal amplitude & 1 & 60.65 & $\mathrm{Sp}=\mathrm{Np}$ \\
Brachynotus & Residuals & 2 & 76.08 & \\
sexdentatus & Tidal amplitude & 1 & 2.20 & $\mathrm{Sp}=\mathrm{Np}$ \\
Macropodia sp. & Residuals & 9 & 1.12 & $\mathrm{Sp}=\mathrm{Np}$ \\
& Tidal amplitude & 1 & 140.86 & $\mathrm{Sp}=\mathrm{Np}$ \\
& Residuals & 7 & 43.29 & \\
\hline
\end{tabular}

Results of four-way ANOVA tests on the relative abundance of megalopae indicated:

(a) In spring tides, the flux of Pisidia longicornis and Brachynotus sexdentatus megalopae was greatest in nocturnal floods $(P<0.01)$ (bottom $>$ surface, for $P$. longicornis; bottom for $B$. sexdentatus) and, in a minor degree, in nocturnal zebbs close to the bottom (Tables 3 and 4); a major flux of Panopeus africanus megalopae was also observed in nocturnal floods $(P<0.01)$, and the flux close to the bottom was significantly higher than at surface but only during the night; conversely, the flux of Ilia nucleus and Nepinnotheres pinnotheres did not show significant $(P>0.05)$ changes related to diel/tidal/depth conditions (Table 3).

(b) In neap tides, the flux of Pisidia longicornis megalopae was significantly higher during night tides $(P<0.05)$; the flux of Panopeus africanus megalopae was maximal close to the bottom in nocturnal flood and, in a minor degree, in diurnal flood, and differences between both floods changed from date to date $(P<0.05)$ (Table 3$)$, although the a posteriori test
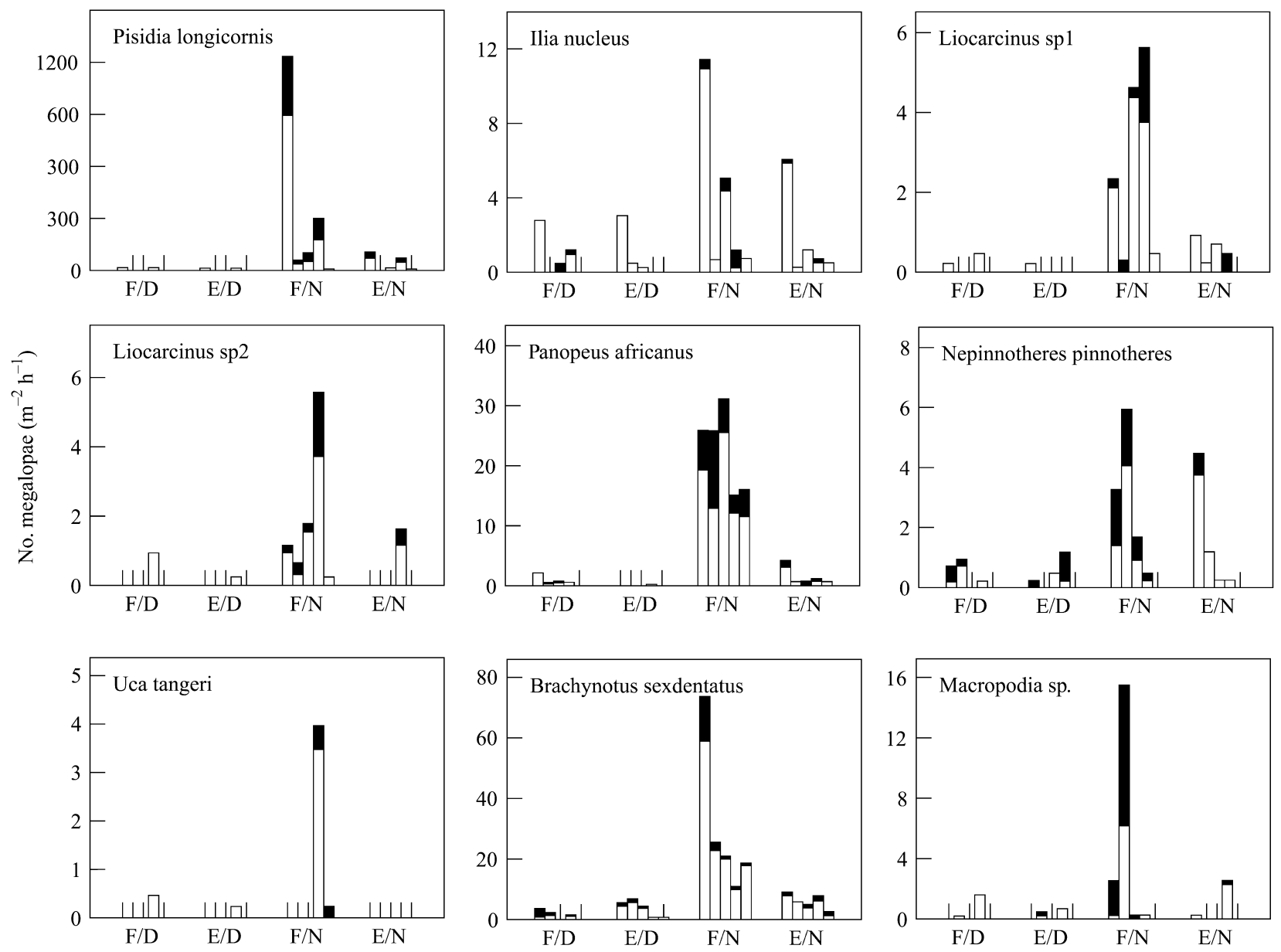

Fig. 4. Flux of crustacean decapod megalopae in the Río San Pedro inlet at each diel/tidal/depth situation during the $25 \mathrm{~h}$ sampling series in spring tides. $\square$, bottom; $\mathbf{\square}$, surface. $\mathrm{F}=$ flood; $\mathrm{E}=\mathrm{ebb} ; \mathrm{D}=$ day; $\mathrm{N}=$ night. 

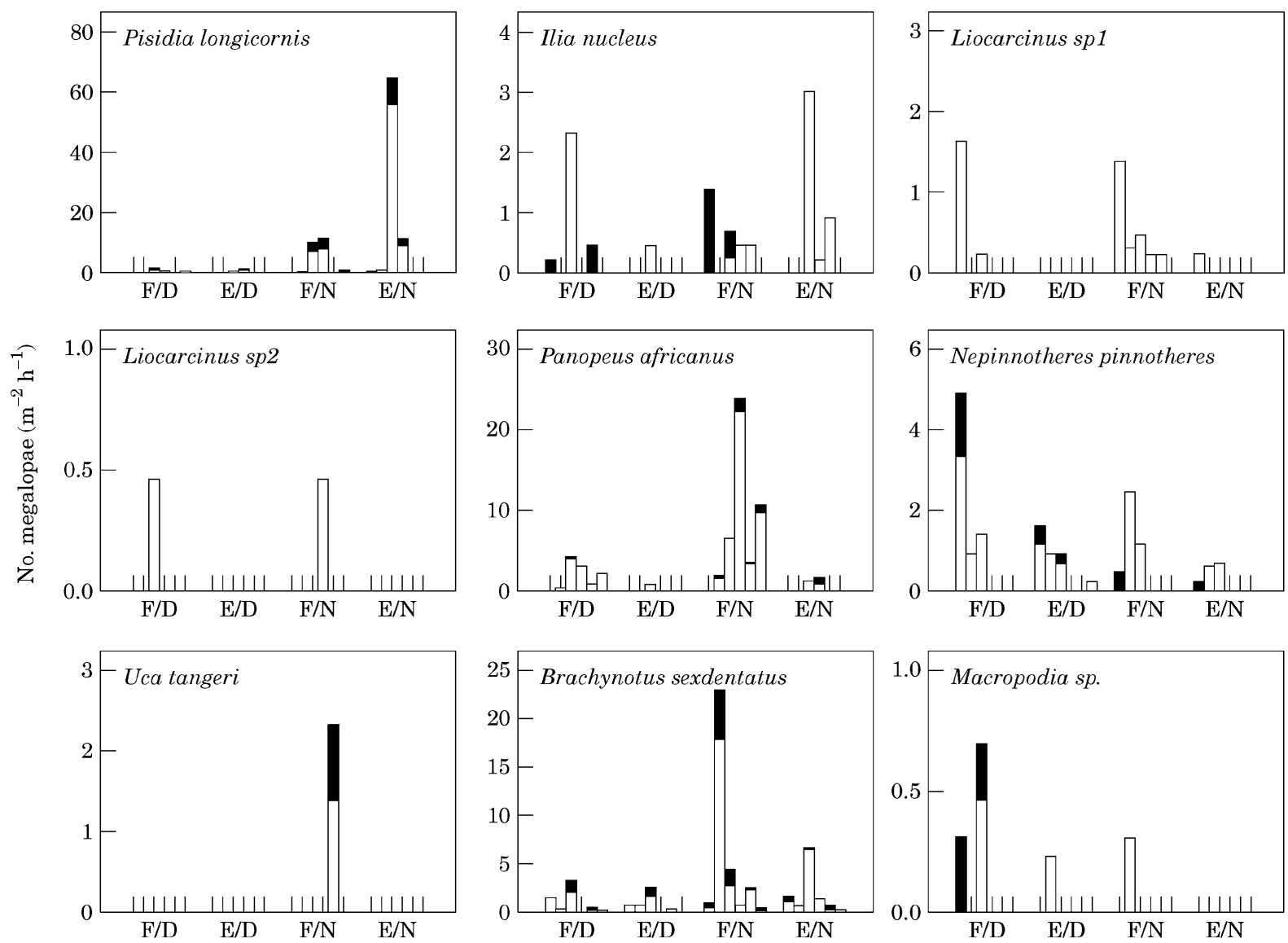

Fig. 5. Flux of crustacean decapod megalopae in the Río San Pedro inlet at each diel/tidal/depth situation during the 25-h sampling series in neap tides. $\square$, bottom; $\mathbf{\square}$, surface. $\mathrm{F}=$ flood; $\mathrm{E}=$ ebb; $\mathrm{D}=$ day; $\mathrm{N}=$ night.

failed to detect as to which values were statistically different (Table 4); the flux of Nepinnotheres pinnotheres megalopae was higher close to the bottom $(P<0.05)$; while megalopae of Brachynotus sexdentatus and Ilia nucleus did not show significant changes related to diel/tidal/depth conditions $(P>0.05)$ (Table 3).

In summary, from the five most abundant species, only Panopeus africanus megalopae were always more abundant during flood than ebb tides, suggesting a reinvasion of the inlet, while for Pisidia longicornis and Brachynotus sexdentatus such differences were only significant in spring tides. Furthermore, for all these species, the tidal situation - vertical position interaction effect, did not suggest a flood-tide transport of megalopae by ascending within the water column, but a migration from the sediment to the water column, and vice versa. Conversely, differences in flux related to tidal cycle were not significant for Ilia nucleus and Nepinnotheres pinnotheres indicating that, although megalopae of these species were present in the inlet, they were not clearly re-invading it.

\subsection{Tidal amplitude cycle and megalopal patterns}

As it was explained in Section 2.3, samples from each 'diel/tidal' situation were pooled within each date before statistical analysis. Consequently, there were certain differences in light conditions, but a same diel/tidal condition in spring and neap tides was considered (Fig. 2) and also from date to date (Figs. 6-8). To assess if these changes in tidal-light conditions could be leading us to misunderstand the real behaviour of megalopae, the relative flux has been represented sample by sample and date by date for the nine most abundant species (Figs. 6-8). The 25-h cycles with less than 10 megalopae were not represented and the flux of megalopae in the inlet was considered to be 0 during slack water at high and low tides.

When the flux of megalopae of these species was analysed, three different patterns of behaviour were observed. A first type of behaviour was of species that always showed a maximal input at nocturnal flood tides and, consequently, was more abundant in the middle of the night at spring tides and at late night during neap tides. The clearest example of this pattern was the mud 
Table 3

Results of four-way ANOVAs of the effects of tidal and diel cycles, vertical position and date on the relative (within each $25 \mathrm{~h}$ series) flux of megalopae

\begin{tabular}{|c|c|c|c|c|c|c|c|c|c|c|}
\hline \multirow[b]{2}{*}{ Source of variation } & \multicolumn{2}{|c|}{ Pisidia longicornis } & \multicolumn{2}{|c|}{ Ilia nucleus } & \multicolumn{2}{|c|}{ Panopeus africanus } & \multicolumn{2}{|c|}{$\begin{array}{l}\text { Nepinnotheres } \\
\text { pinnotheres }\end{array}$} & \multicolumn{2}{|c|}{$\begin{array}{l}\text { Brachynotus } \\
\text { sexdentatus }\end{array}$} \\
\hline & $\mathrm{df}$ & Mean square & $\mathrm{df}$ & Mean square & $\mathrm{df}$ & Mean square & $\mathrm{df}$ & Mean square & $\mathrm{df}$ & Mean square \\
\hline \multicolumn{11}{|l|}{ Spring tides } \\
\hline Tide (flood/ebb) & 1 & $1375.37 * *$ & 1 & 752.84 & 1 & $3707.80^{* *}$ & 1 & 461.89 & 1 & $496.92 *$ \\
\hline Light (day/night) & 1 & $6222.95^{* *}$ & 1 & 687.29 & 1 & $4857.24 * *$ & 1 & 1337.78 & 1 & $2628.79^{* *}$ \\
\hline Depth (surface/bottom) & 1 & $168.77^{*}$ & 1 & 1349.77 & 1 & $958.88 * *$ & 1 & 178.10 & 1 & $2550.41^{* *}$ \\
\hline Date & 4 & 6.57 & 2 & 54.38 & 4 & 10.02 & 1 & 20.01 & 4 & 13.28 \\
\hline Tide $\times$ Light & 1 & $1742.91 * *$ & 1 & 15.82 & 1 & $2130.80 * *$ & 1 & 1.59 & 1 & $1153.39^{* *}$ \\
\hline Tide $\times$ depth & 1 & $75.79^{*}$ & 1 & 3.36 & 1 & 322.05 & 1 & 29.45 & 1 & 219.49 \\
\hline Tide $\times$ date & 4 & 41.84 & 2 & 93.07 & 4 & 18.00 & 1 & 319.40 & 4 & 30.72 \\
\hline Light $\times$ depth & 1 & $93.24 *$ & 1 & 305.71 & 1 & $339.85^{*}$ & 1 & 268.44 & 1 & $1054.51^{*}$ \\
\hline Light $\times$ date & 4 & 4.42 & 2 & 237.92 & 4 & 5.62 & 1 & 3.23 & 4 & 54.33 \\
\hline Depth $\times$ date & 4 & 24.97 & 2 & 66.09 & 4 & 38.02 & 1 & 95.31 & 4 & 24.25 \\
\hline Tide $\times$ light $\times$ depth & 1 & $62.72 *$ & 1 & 0.23 & 1 & 92.87 & 1 & 140.43 & 1 & $667.98^{*}$ \\
\hline Tide $\times$ light $\times$ date & 4 & 32.51 & 2 & 398.97 & 4 & 30.45 & 1 & 122.85 & 4 & 88.29 \\
\hline Tide $\times$ depth $\times$ date & 4 & 10.62 & 2 & 17.44 & 4 & 46.79 & 1 & 37.22 & 4 & 30.43 \\
\hline Light $\times$ depth $\times$ date & 4 & 24.11 & 2 & 105.04 & 4 & 17.32 & 1 & 0.41 & 4 & 4.06 \\
\hline Residuals & 4 & 8.06 & 2 & 162.7 & 4 & 42.42 & 1 & 26.6 & 4 & 53.51 \\
\hline \multicolumn{11}{|l|}{ Neap tides } \\
\hline Tide (flood/ebb) & 1 & $133.68^{*}$ & 1 & 61.85 & 1 & $3447.49^{* *}$ & 1 & 182.39 & 1 & 403.64 \\
\hline Light (day/night) & 1 & $1804.07^{*}$ & 1 & 20.64 & 1 & $111.14^{* *}$ & 1 & 312.12 & 1 & 1082.25 \\
\hline Depth (surface/bottom) & 1 & 545.78 & 1 & 1181.43 & 1 & $3077.55^{* *}$ & 1 & $1980.92 *$ & 1 & 1475.65 \\
\hline Date & 1 & 24.53 & 1 & & 3 & 12.30 & 2 & 9.34 & 3 & 43.79 \\
\hline Tide $\times$ light & 1 & 148.28 & 1 & 538.45 & 1 & $627.04 * *$ & 1 & 1.79 & 1 & 131.91 \\
\hline Tide $\times$ depth & 1 & 129.49 & - & 0.00 & 1 & $1926.84 * *$ & 1 & 144.86 & 1 & 10.65 \\
\hline Tide $\times$ date & 1 & 87.13 & - & & 3 & $55.39 *$ & 2 & 31.22 & 3 & 155.01 \\
\hline Light $\times$ depth & 1 & 239.83 & 1 & 10.91 & 1 & $312.99 * *$ & 1 & 25.67 & 1 & 22.99 \\
\hline Light $\times$ date & 1 & 10.33 & - & & 3 & $100.60 * *$ & 2 & 314.52 & 3 & 92.99 \\
\hline Depth $\times$ date & 1 & 8.31 & - & & 3 & $35.80^{*}$ & 2 & 510.95 & 3 & 12.72 \\
\hline Tide $\times$ light $\times$ depth & 1 & 70.34 & - & & 1 & $248.11 * *$ & 1 & 0.56 & 1 & 31.82 \\
\hline Tide $\times$ light $\times$ date & 1 & 248.98 & - & & 3 & $75.47 *$ & 2 & 91.14 & 3 & 257.02 \\
\hline Tide $\times$ depth $\times$ date & 1 & 34.49 & - & & 3 & 25.51 & 2 & 30.82 & 3 & 64.0 \\
\hline Light $\times$ depth $\times$ date & 1 & 13.67 & - & & 3 & 1.98 & 2 & 158.99 & 3 & 147.96 \\
\hline Residuals & 1 & 49.12 & 1 & 235.89 & 3 & 3.31 & 2 & 62.25 & 3 & 187.7 \\
\hline
\end{tabular}

$* P<0.05 ; * * P<0.01 ;-$, insufficient degrees of freedom to estimate interaction effects.

Table 4

Results of a posteriori Student-Newman-Keuls tests applied to factors detected to be significant by ANOVAs (see Table 3)

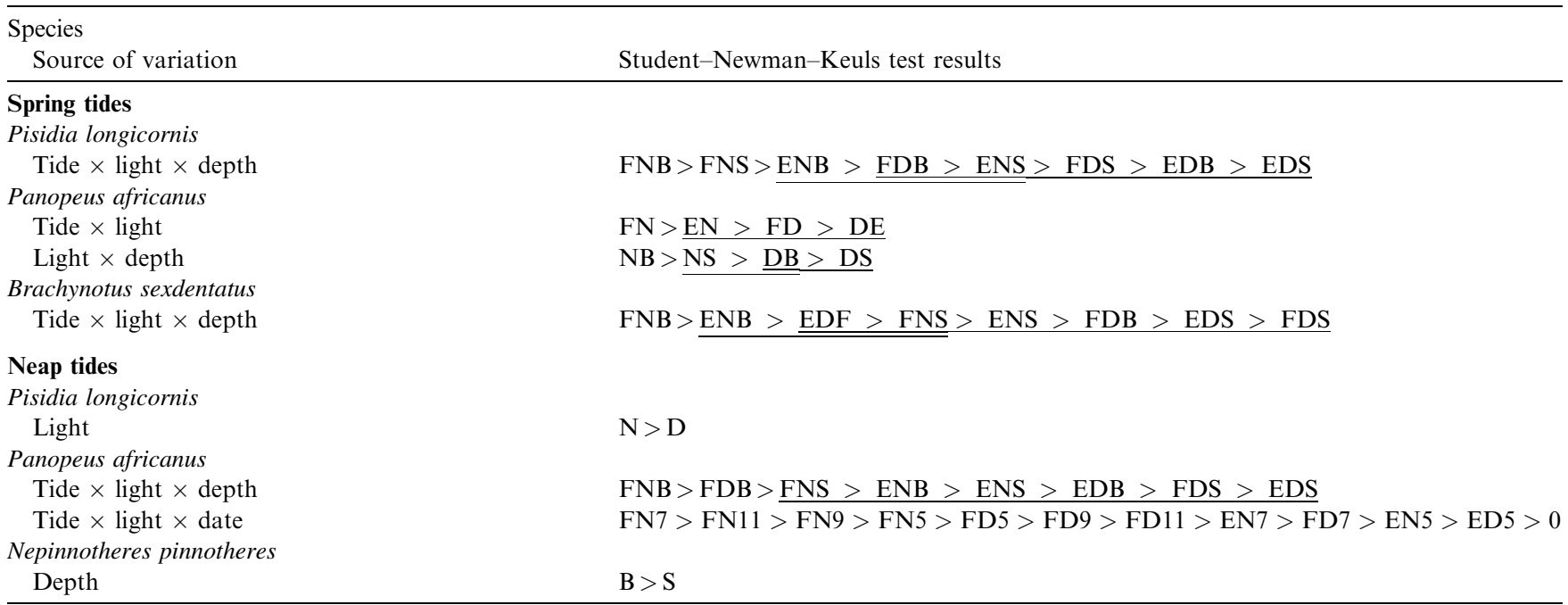

For each test, fluxes estimated in situations joined by underline were not significantly different at $5 \%$ level. N, night; D, day; F, flood; E, ebb; S, surface; B, bottom; 1 to 11,17 June to 31 August data sets, respectively. 
crab Panopeus africanus and Uca tangeri. It seemed to be also the pattern of Liocarcinus spp., although their maximal fluxes occurred at diurnal flood in some neap tides. A second type corresponded to species whose megalopae were collected mainly from dark to dawn, Pisidia longicornis being the best example. For this species, a certain tidal displacement in maximal flux of megalopae was observed between spring and neap tides, but with maxima always occurring in nocturnal samples (Figs. 6 and 7). Brachynotus sexdentatus megalopae also showed such a pattern, except on 17 June (neap tide). Finally, a third type, represented by Ilia nucleus, Nepinnotheres pinnotheres and Macropodia sp., comprised species whose megalopae did not show a clear diel/tidal pattern.

From these three patterns, only the first one always resulted in a consistent pattern of net input (re-invasion) of megalopae to the inlet; while statistical conclusions derived from ANOVAs may have been more affected by the inexact assessment of the diel phase for the species included in the second group.

In general, within each tidal phase (four samples), maximal flux did not occur regularly for any species in spring or neap tides (Figs. 6-8).

\section{Discussion}

According to the available information (Drake et al., 1998; Rodríguez et al., 1997; this study), the two general life history strategies expected for species inhabiting and spawning in estuarine habitats, were observed in the Río San Pedro inlet (Table 5). First zoea of five species seemed to be exported simply by a synchronization of the larval release with a suitable tidal phase (Drake et al., 1998). Of these, megalopae of four species (Panopeus africanus, Uca tangeri and the two species of Liocarcinus) showed a consistent pattern of re-invasion of the inlet
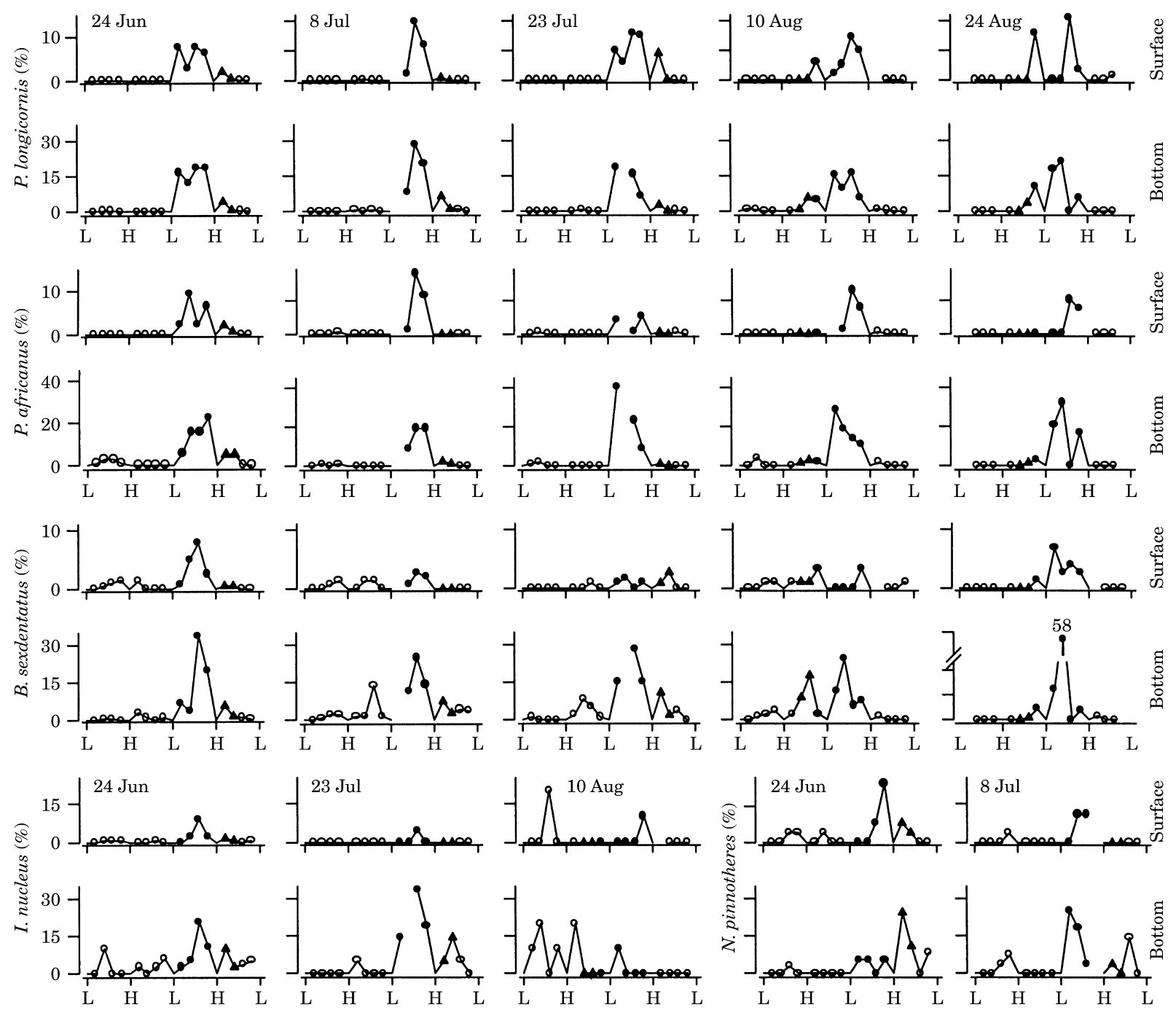

Fig. 6. Relative (\%) flux of megalopae of the five most abundant decapod species along the 25 -h sampling series conducted in spring tides at the Río San Pedro inlet. For each species, sets with less than 10 megalopae were excluded. $\bigcirc$, diurnal; $\boldsymbol{\bullet}$, nocturnal; $\boldsymbol{\Lambda}$, crepuscular; H, high tide; L, low tide. 

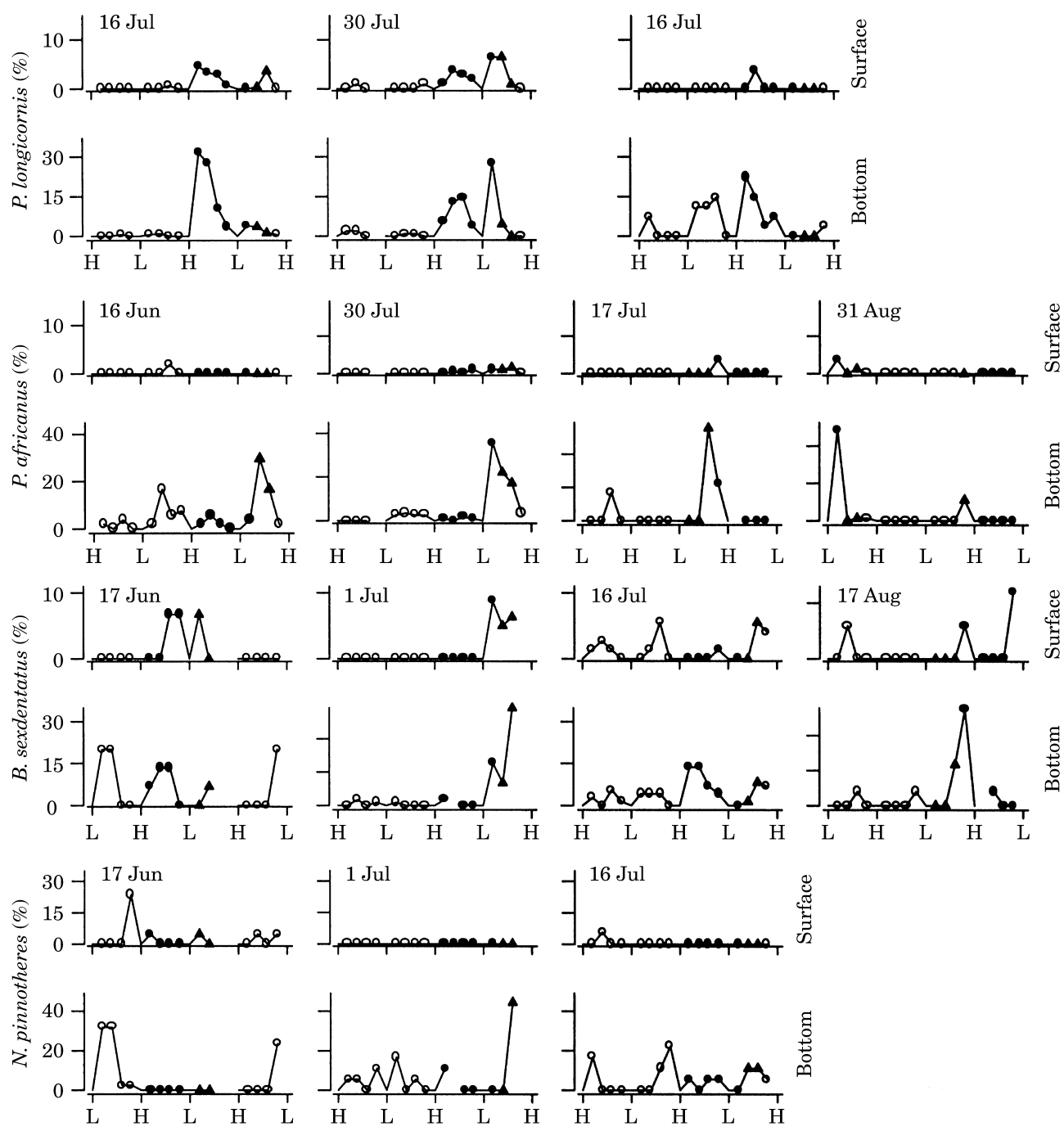

Fig. 7. Relative (\%) flux of megalopae of the five most abundant decapod species along the 25 -h sampling series conducted in neap tides at the Río San Pedro inlet. For each species, sets with less than 10 megalopae were excluded. $\bigcirc$, diurnal; $\bullet$, nocturnal; $\boldsymbol{\Lambda}$, crepuscular; H, high tide; L, low tide.

during the studied period, being more abundant in the water column during (mainly nocturnal) floods. Nevertheless, the number of Uca and Liocarcinus megalopae was low and these species were not included in statistical analyses. Megalopae of the fifth species (Brachynotus sexdentatus) also seemed to be re-invading the inlet although with some exceptions on neap tides. Conversely, importation or retention of first larval zoea was found for four species (Pisidia longicornis, Ilia nucleus, Nepinnotheres pinnotheres and Macropodia sp.) suggesting that these species may complete their life cycle within the studied inlet and/or in the adjacent bay (Drake et al., 1998; González-Gordillo and Rodríguez, in press). Megalopae of these species were collected in the inlet, but they did not show a clear pattern of re-invasion. For I. nucleus and $N$. pinnotheres, no significant differences were observed between the total number of megalopae going into and out of the studied system, while for $P$. longicornis, a net input of megalopae was only recorded in spring tides (Table 4). Due to the low number of megalopae of Macropodia sp. collected, this species was not included in statistical analyses. Since the sampling station was located close to the mouth of the Río San Pedro inlet, it is possible to hypothesize that, during the study period, megalopae of the first group of species were re-invading the inlet, while megalopae of the species included in the second group were just looking for a suitable assessment. For the latter, a higher input or output of megalopae may depend on their different abundance in the Bay of Cádiz and in the Río San Pedro at each sampling occasion.

Although samples were only taken close to the surface and to the bottom of the channel, the results of the present study suggest that megalopae of the species that did not complete their life cycle within the studied system and were re-invading the inlet by tidal vertical migrations between the water column and the sediment, in response to the alternating tidal condition, 
Spring tides
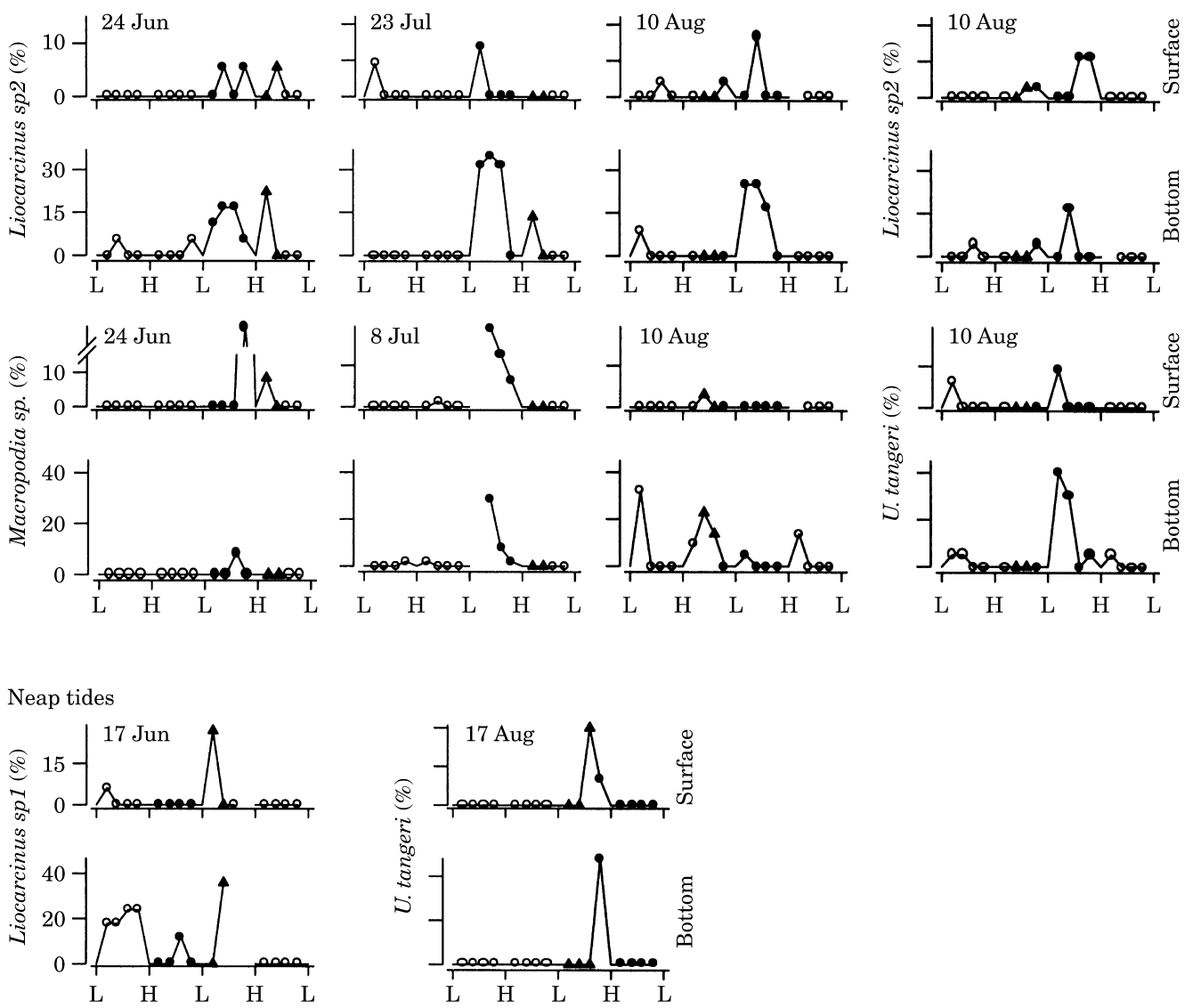

Fig. 8. Relative (\%) flux of megalopae of Liocarcinus spp., Macropodia sp. and Uca tangeri along the 25-h sampling series conducted in spring and neap tides at the Río San Pedro inlet. For each species, sets with less than 10 megalopae were excluded. $\bigcirc$, diurnal; $\boldsymbol{\bullet}$, nocturnal; $\boldsymbol{\Lambda}$, crepuscular; $\mathrm{H}$, high tide; L, low tide.

Table 5

Distribution of the nine abundant species, percentages represented for different larval stages and derived life history in the area

\begin{tabular}{|c|c|c|c|c|}
\hline Species & Adults $^{\mathrm{a}}$ & Zoea $\mathrm{I}^{\mathrm{a}}$ & $\begin{array}{l}\text { Later larval } \\
\text { stages }^{\mathrm{a}}\end{array}$ & (No. Z) Life history strategy in the studied area ${ }^{a, b}$ \\
\hline Pisidia longicornis & $\begin{array}{l}\text { (I, B) Intertidal under } \\
\text { stones }\end{array}$ & 98.6 & 1.4 & $\begin{array}{l}\text { (2) Importation or retention of first zoea in the inlet; } \\
\text { not consistent re-invasion of the inlet by megalopae } \\
\text { in neap tides }\end{array}$ \\
\hline Macropodia sp. & (I, B) Subtidal & 82.2 & 17.8 & $\begin{array}{l}\text { (2) May complete the life cycle in the inlet; not } \\
\text { consistent re-invasion of the inlet by megalopae }\end{array}$ \\
\hline Ilia nucleus & (B) Muddy subtidal & 66.4 & 32.6 & $\begin{array}{l}\text { (3?) Complete the life cycle within the bay of Cádiz; } \\
\text { not consistent re-invasion of the inlet by megalopae }\end{array}$ \\
\hline Liocarcinus spp. & $\begin{array}{l}\text { (I, B) Muddy/sandy } \\
\text { subtidal }\end{array}$ & 99.8 & 0.2 & $\begin{array}{l}\text { (5) Exportation of first zoea and re-invasion by } \\
\text { megalopae }\end{array}$ \\
\hline Panopeus africanus & (I) Muddy/stony intertidal & 99.5 & 0.5 & $\begin{array}{l}\text { (4) Exportation of first zoea and re-invasion by } \\
\text { megalopae }\end{array}$ \\
\hline Nepinnotheres pinnotheres & (I, B) On bivalves & 96.4 & 3.6 & $\begin{array}{l}\text { (2) Importation or retention of first zoea in the inlet; } \\
\text { not consistent re-invasion of the inlet by megalopae }\end{array}$ \\
\hline Uca tangeri & (I) Muddy/sandy intertidal & 99.9 & 0.1 & $\begin{array}{l}\text { (5) Exportation of first zoea and re-invasion by } \\
\text { megalopae }\end{array}$ \\
\hline Brachynotus sexdentatus & $\begin{array}{l}\text { (I, B) Muddy/stony } \\
\text { intertidal }\end{array}$ & 96.2 & 3.8 & $\begin{array}{l}\text { (5) Exportation of first zoea; not consistent } \\
\text { re-invasion of the inlet by megalopae in neap tides }\end{array}$ \\
\hline
\end{tabular}

(No. Z), number of zoeal stages; sources of the information.

B, Bay of Cádiz; I, Río San Pedro inlet.

${ }^{\text {a }}$ Rodríguez et al., 1997 and Drake et al., 1998.

b The present study. 
seemed to move up into the water column during flood and move down to the sediment during ebb to expedite upstream transport. This behaviour can be classified as a selective tidal stream transport mechanism and has been previously invoked for megalopae re-invading other estuarine habitats (Little \& Epifanio, 1991; Olmi, 1994; Queiroga, Costlow, \& Moreira, 1994). Conversely, vertical migrations of megalopae within the water column, resulting in distributions closer to the surface during flood than during ebb, as observed for Callinectes sapidus or Carcinus maenas megalopae (Olmi, 1994; Queiroga, 1998), were not found in this study. This tidal-related activity pattern, with megalopae more active during flood than during ebb, may have an endogenous component for some species (Zeng \& Naylor, 1996), while they may rely upon external cues (e.g. changes in temperature, salinity, hydrostatic pressure, turbulence) for other species (Tankersley et al., 1995). In this study, neither salinity nor temperature showed a tidal pattern that justified the observed differences in the tidal abundance of megalopae. On the other hand, fluctuations of the tidal level in the study area are clear at each tide; thus megalopae could respond by moving up when hydrostatic pressure was increased (Jacoby, 1982; Sulkin, 1984). According to Forward and Rittschof (1994), the swimming activity of megalopae is inhibited in estuarine waters by high light intensities, which cause sinking to the bottom during the day, with a return to the water column during the night.

Nevertheless, the sampling site was located close to the mouth of the inlet, where there was a high hydrodynamism and where differences in speed current between surface and bottom were not considerable (Fig. 2 ), it is possible that such a vertical migration of megalopae occurs in inner zones of the inlet, where a stronger vertical gradient of current speed has been observed (Drake et al., 1998). In areas with strong tidal currents and irregular bottom topography, vertical mixing of the water column may mask any larval movements (Young \& Chia, 1987). Other possible explanation can be predation avoidance. This zone is an important nursery area for fish (Drake \& Arias, 1993); hence, the predation pressure by fish larvae could be determining this behaviour.

Such a tidal-related pattern in flux was not observed for the species that may complete their life cycle within the study area. The exception was Pisidia longicornis megalopae that were significantly more abundant on floods in spring tides (Table 4). Nevertheless, this net input may have been just a fortuitous result of its major nocturnal abundance in the water column. In fact, a certain tidal displacement in maximal flux of $P$. longicornis megalopae was observed between spring and neap tides related to differences in tidal/light conditions (Fig. 2), resulting in that maximal flux may occur at ebb in neap tides but always in authentic 'nocturnal' samples
(Figs. 6 and 7). Such a clear pattern of almost exclusive nocturnal occurrence of $P$. longicornis megalopae in the water column has been previously observed in the Catalan coast (NW Mediterranean) (Abelló \& Guerao, 1999). Since the reproductive period of the species in the studied system took place all year round (Drake et al., 1998), it is expected that its nocturnal abundance does not lead always to a net input of megalopae to the inlet. Conversely, spawning of Brachynotus sexdentatus, the other species whose megalopae were also more abundant during night-time hours on spring tides, occurs mainly during warm months (González-Gordillo \& Rodríguez, in press). Thus, since the total volume of water flowing during $25 \mathrm{~h}$ into the inlet was always higher in spring tides than in neap tides, the observed nocturnal pattern of their megalopae in spring tides may represent a consistent mechanism of re-invasion of the studied inlet.

Because the relationship between tidal and diel cycles was not constant from one date to another, the study was designed to sample correctly the tidal cycles and could not assess diel cycles with the same accuracy. At each date, the four samples taken within each tidal/diel situation were not independent and it was necessary to pool them into a single estimate before statistical analyses. Consequently, between spring and neap tides, and also from date to date, there were certain differences in light conditions, but the same diel/tidal condition was considered. In this study, therefore, it is necessary to be cautious concerning megalopae behaviour related to light, derived from statistically analyses. As megalopae of Pisidia longicornis seem to be very sensitive to changes in light, its highest flux on nocturnal 'flood' in spring tides may have been an artefact due to the fact that in these nocturnal flood, only authentic nocturnal samples were included, while crepuscular (dawn) and early-day samples were also included in spring tide ebbs. According to the behavioural pattern showed for megalopae of the other species (Figs. 6-8), this inexactitude in assessing diel phases did not seem to have affected the results of statistical analyses.

On average, there was a higher flux of megalopae on spring tides. The interdate variation in megalopal abundance was, however, so considerable that such differences were only significant for two of the nine most abundant species (Table 2). Especially for species that have spent the zoeal stage in open sea, this pattern was expectable: the higher hydrodynamism on spring tides may facilitate the selective tidal stream transport of megalopae into the inlet. Nevertheless, megalopal arrival at the coast, a necessary step for the re-invasion of adult habitats, occurs in distinct pulses associated with hydrographic features, such as strong winds (Little \& Epifanio, 1991), which may have contributed to the observed interdate variation.

The nine most abundant species analysed in this study (Table 5), species whose first zoeal stage was 
exported from the inlet and whose megalopae seemed to re-invade it, have a relatively longer larval period (five zoeal stages, except Panopeus africanus with four). Species that may complete their life cycle within the bay and/or the inlet, however, showed a relatively short larval period (two zoeal stages, except Ilia nucleus with three) and their zoeae have large spines or spines with a peculiar disposition. Both features may represent antipredatory adaptations for species whose larvae were retained in estuarine habitats, where planktivorous fishes were more abundant. Morgan (1987) concluded that, with some exceptions, the exported zoeae have shorter spines and smaller bodies than the retained zoeae. The results of the present study also suggest a relationship between the duration (number of zoeal stages) of the larval period and the life-cycle strategy of the species. No clear connection seemed to exist between adult habitats and life-cycle strategies in the studied inlet.

In several families of decapod, conspecific individuals living under different environmental conditions can show development with a variable number of stages, a process that seems to be an adaptive response to certain combinations of environmental conditions perceived to be adverse (Gore, 1995). With the exception of Majidae, whose species always have two zoeal stages before megalopae, the other brachyuran families considered in this study (Table 1) might show a certain variation in the number of zoeal stages. In the case of Pinnotheridae, the species $N$. pinnotheres has an abbreviated development: two zoeal stages, compared with the three, four or five zoeal stages presented by the majority of the other described pinnotherids (Rabalais \& Gore, 1985). Nevertheless, according to the available information (Atkins, 1955; Clark, 1984; Cuesta, Schubart, \& Rodríguez, 2000; Rodríguez \& Jones, 1993; Rodríguez \& Paula, 1993), all the species collected in the Río San Pedro showed the number of zoeal stages that are the norm (numerically predominant within their populations) for the species.

\section{Acknowledgements}

We thank two reviewers for contributions that improved earlier version of this manuscript. This research was partially supported by grants from Consejo Superior de Investigaciones Científicas (CSIC) and Consejería de Medio Ambiente de la Junta de Andalucía, Spain and by post-doctoral fellowships to J.I.G.-G. (SFRH/ BPD/1596/2000) from the Ministério da Ciência e da Tecnologia (FCT), Portugal.

\section{References}

Abelló, P., \& Guerao, G. (1999). Temporal variability in the vertical and mesoscale spatial distribution of crab megalopae (Crustacea:
Decapoda) in the Northwestern Mediterranean. Estuarine, Coastal and Shelf Science 49, 129-139.

Atkins, D. (1955). The post-embryonic development of British Pinnotheres (Crustacea). Proceedings of the Zoological Society of London 124, 687-715.

Boehlert, G. W., \& Mundy, B. C. (1988). Roles of behavioural and physical factors in larval and juvenile fish recruitment to estuarine nursery areas. American of Fishery Society Symposium 3, 51-67.

Clark, P. F. (1984). A comparative study of zoeal morphology in the genus Liocarcinus (Crustacea: Brachyura: Portunidae). Zoological Journal of the Linnean Society 82, 273-290.

Cronin, T. W. (1982). Estuarine retention of larvae of the crab Rhithropanopeus harrisii. Estuarine, Coastal and Shelf Science 15, 207-220.

Cuesta, J. A., Schubart, C. D., \& Rodríguez, A. (2000). Larval development of Brachynotus sexdentatus (Risso, 1827) (Decapoda, Brachyura) reared under laboratory conditions, with notes on larval characters of the Varunidae. Invertebrate Reproduction and Development 38, 207-223.

Dittel, A. I., \& Epifanio, C. E. (1990). Seasonal and tidal abundance of crab larvae in a tropical mangrove system, Gulf of Nicoya, Costa Rica. Marine Ecology Progress Series 65, 25-34.

Drake, P., \& Arias, A. M. (1993). Larval feeding habits and diel rhythms of four species of marine fish in a tidal creek of Cádiz Bay (Spain). In B. T. Walther, \& H. J. Fyhn (Eds.), Physiology and biochemistry of fish larvae (pp. 153-159). Bergen: University of Bergen.

Drake, P., Arias, A. M., \& Rodríguez, A. (1998). Seasonal and tidal abundance patterns of decapod crustacean larvae in a shallow inlet (SW Spain). Journal of Plankton Research 20, 585-601.

Epifanio, C. E. (1988). Transport of invertebrate larvae between estuaries and the continental shelf. American of Fishery Society Symposium 3, 104-114.

Epifanio, C. E. (1995). Transport of blue crab (Callinectes sapidus) larvae in the waters off mid-Atlantic states. Bulletin of Marine Science 57, 713-725.

Forward, R. B., \& Rittschof, D. (1994). Photoresponses of crab megalopae in offshore and estuarine waters: implications for transport. Journal of Experimental Marine Biology and Ecology $182,183-192$.

González-Gordillo, J. I., \& Rodríguez, A. Comparative seasonal and spatial distribution of decapod larvae assemblages in three coastal zones off the southwestern Iberian Peninsula. Acta Oecologica (in press).

Gore, R. H. (1995). Molting and growth in decapod larvae. In A. M. Wenner (Ed.), Larval growth Vol. 2 (pp. 1-65). Rotterdam: Balkema.

Jacoby, C. A. (1982). Behavioral responses of the larvae of Cancer magister Dana (1852) to light, pressure, and gravity. Marine Behaviour and Physiology 8, 267-283.

Johnson, D. R., \& Perry, H. M. (1999). Blue crab larval dispersion and retention in the Mississippi bight. Bulletin of Marine Science 65 , $129-149$

Little, K. T., \& Epifanio, C. E. (1991). Mechanism for the re-invasion of an estuary by two species of brachyuran megalopae. Marine Ecology Progress Series 68, 235-242.

Morgan, S. G. (1987). Morphological and behavioural antipredatory adaptations of decapod zoeae. Oecologia 73, 393-400.

Morgan, S. G. (1995). Life and death in the plankton: larval mortality and adaptation. In L. R. McEdward (Ed.), Ecology of marine invertebrate larvae (pp. 279-321). New York: CRC Marine Sciences Series.

Olmi, E. J., III. (1994). Vertical migration of blue crab Callinectes sapidus megalopae: implications for transport in estuaries. Marine Ecology Progress Series 113, 39-54.

Pereira, F., Pereira, R., \& Queiroga, H. (2000). Flux of decapod larvae and juveniles at a station in the lower Canal de Mira (Ria de Aveiro, Portugal) during one lunar month. Invertebrate Reproduction and Development 38, 183-206. 
Queiroga, H. (1998). Vertical migration and selective tidal stream transport in the megalopae of the crab Carcinus maenas. Hydrobiologia 375/376, 137-149.

Queiroga, H., Costlow, J. D., \& Moreira, M. H. (1994). Larval abundance patterns of Carcinus maenas in Canal de Mira (Ria de Aveiro, Portugal). Marine Ecology Progress Series 111, 63-72.

Queiroga, H., Costlow, J. D., \& Moreira, M. H. (1997). Vertical migration of the crab Carcinus maenas first zoea in an estuary: implications for tidal stream transport. Marine Ecology Progress Series 149, 121-132.

Rabalais, N., \& Gore, R. H. (1985). Abbreviated development in decapod larvae. In A. M. Wenner (Ed.), Larval growth Vol. 2 (pp. 67-126). Rotterdam: Balkema.

Rodríguez, A., Drake, P., \& Arias, A. M. (1997). Reproductive periods and larval abundance patterns of crabs Panopeus africanus and Uca tangeri in a shallow inlet (SW Spain). Marine Ecology Progress Series 149, 133-142.

Rodríguez, A., \& Jones, D. A. (1993). Larval development of Uca tangeri (Eydoux, 1835) (Decapoda: Ocypodidae) reared in the laboratory. Journal of Crustacean Biology 13, 309-321.

Rodríguez, A., \& Paula, J. (1993). Larval and postlarval development of the mud crab Panopeus africanus A. Milne Edwards (Decapoda:
Xanthidae) reared in the laboratory. Journal of Crustacean Biology 13, 296-308.

Sandifer, P. A. (1975). The role of pelagic larvae in recruitment to populations of adult decapod crustacean in the York River Estuary and adjacent lower Chesapeake Bay, Virginia. Estuarine, Coastal and Shelf Science 3, 269-279.

Sulkin, S. D. (1984). Behavioural basis of depth regulation in the larvae of brachyuran crabs. Marine Ecology Progress Series 15, 181-205.

Tankersley, R. A., McKelvey, L. M., \& Forward, R. B. (1995). Responses of estuarine crab megalopae to pressure, salinity and light: implications for flood-tide transport. Marine Biology 122, 391-400.

Wehrtmann, I. S., \& Dittel, A. I. (1990). Utilisation of floating mangrove leaves as a transport mechanism of estuarine organisms, with emphasis on decapod crustacean. Marine Ecology Progress Series 60, 67-73.

Young, C. M., \& Chia, F. S. (1987). Abundance and distribution of pelagic larvae as influenced by predation, behaviour, and hydrographic factors. In A. C. Giese, J. S. Pearse, \& V. B. Pearse (Eds.), Reproduction of marine invertebrates Vol. 9 (pp. 385-463). Palo Alto: Blackwell.

Zeng, C., \& Naylor, E. (1996). Occurrence in coastal waters and endogenous tidal swimming rhythms of late megalopae of the shore crabs Carcinus maenas: implications for onshore recruitment. Marine Ecology Progress Series 136, 69-79. 